${ }^{1}$ Department of Rheumatology, Shandong provincial Hospital, Shandong Univeristy, Jinan, China

2 Department of Osteology, Handan central Hospital, Handan, China

E-mail: zhangyuanchao1949@yeah.net, panzhenglun@gmail.com

\title{
THE RELATIONSHIP BETWEEN SNPS IN THE GENES OF TLR SIGNAL TRANSDUCTION PATHWAY DOWNSTREAM ELEMENTS AND RHEUMATOID ARTHRITIS SUSCEPTIBILITY
}

Toll-like receptors (TLRS) play an important role in the induction and regulation of the innate immune system or adaptive immune responses. Genetic variations within human TLRs have been reported to be associated with rheumatoid arthritis (RA). This study was conducted to investigate correlation between SNP of downstream mononucleotide in signal transduction of Toll-like receptors and predisposing genes of RA. There was obviously correlative between single nucleotide polymorphism and predisposing genes of $R A$. $G$-type of IL-1RAP rs 766442 may be protecting genes of $R A$, while T-type alleles of IL-6R rs 11265618 and IL-1RAP rs 766442 may be susceptible genes of $R A$. In conclusion, the studies on the nucleis acid polymorphism in TLRs signal pathway contribute to disclose genes' influence on the attack mechanism of $R A$, early diagnosis and treatment of $R A$.

Key words: Rheumatoid arthritis, Toll like receptors, gene, single nucleotide polymorphism.

Introduction. More and more studies have shown that natural immunity plays an important role in the attack and development of rheumatoid arthritis (RA) [1]. Synovitis is the basic pathological changes of RA, and endogenous antigen is relieved and appears in RA synovial joint spontaneously with the stress, damage and necrosis of cells [2]. Activated antigen presentation cell (APC) can be activated by endogenous antigen, through receptors on the surface. APC can capture and deal with antigens, and gather in synovial lining layer to release inflammatory agents. The inflammatory agents could damage cartilage and bone tissue, resulting in the attack of RA [3].Toll-like receptors (TLRs) are a group of receptor molecules serving as the medium of natural immune response. There have been clues of TLRs' significance already in the attack of RA [4, 5]. Both TLR2 and TLR4 are important participating molecules [6]. TLR2 can identify and react with many endogenous antigen epitopes, such as heat shock protein (HSP), hyaluronic acid, fibronectin. While TLR4 can identify taxol, fusion protein, heat shock protein 70 (HSP70),

(c) X. LIU, J. XU, C.D. HU, Z.L. PAN, Y.C. ZHANG, 2014 fibronectin, heparin-sulfate proteoglycan fragments, and human fibrinogen [7-9].

TLR signal transduction includes independent and dependent methods of myeloid differentiation protein 88 (MYD88) [10]. Studies on Single Nucleotide Polymorphism (SNP) in links of TLR signal pathway contribute to learning about the hereditary background of RA attack, and accumulate samples for the study on transformation of genes-properties.

Tanaka et al. [11] found that high levels of IL-6 are shown to correlate with disease severity in RA, and contribute to RA onset and pathogenesis. Clinical trial has shown that the monoclonal $\mathrm{Ab}$ against the IL-6 receptor (IL-6R) is effective in the treatment of RA, which indicates that the IL-6R may play an important role in the RA pathogenesis [12]. IL-1 is the master mediator of inflammatory responses, and has been implicated in RA. The natural IL-1 receptor antagonist protein (IL-1 RAP) could directly oppose the actions of IL-1 [13]. Sacre et al. [14] discovered that the toll-like receptor adaptor protein MYD88 contributes to the inflammatory and destructive processes in a human model of RA. Zhu et al. [15] hypothesized that the TRAF6 is involved in the pathogenesis of inflammation and osteoclast differentiation, and correlated with the severity in RA. So, the present study intends to adopt the case-control approach, takes MYD88, TRAF6, IL-1RAP, IL-6, and $I L-6 R$ as candidate genes, chooses SNP sites, and inquires into the relations between these genes and RA.

Materials and methods. Ethics statements. Written, informed consent was obtained from all patients prior to include into the study. In the case of minors, the consent was provided by the parents. This study was approved by the Ethics committee of the Medical Faculty of Shandong-University Jinan in China. The study protocol adhered to the ethical principles for medical research involving human subjects of the Helsinki Declaration. 
Study population. Our study population comprised 350 individuals of Han people in China, including 162 patients with RA, and 188 healthy unrelated individuals as control. The diagnosis of RA patients was based on established guidelines according to RA diagnostic criteria from America Association of Rheumatism (ACR) in 1987 [16]. All patients excluded autoimmune disease, such as Systemic Lupus Erythematosus (SLE), Dermatomyositis or Polymyositis (DM/PM), diabetes, and thyroid diseases. The RA group would be compared with control group whose members are from physical examination department in Shandong Provincial Hospital. The data for cases with RA and controls were shown in Table 1.

SNP selection. First, data from the National Center for Biotechnology Information were used to select a total of 9 SNPs. These SNPs could capture most of the genetic diversity across the TRAF6 and Myd88 loci (5 SNPs for TRAF6, including: rs76834869, rs116937713, rs5030445, rs117428647, rs5030416; 4 SNPs for MYD88 including: rs7744, rs117598704, rs118081234, rs117074408), with an $\mathrm{r}^{2}$ threshold set to 0.8 and minor allele frequency (MAF) of $10 \%$, according to the information of CHB of the HapMap project. Secondly, the SNPs primer or probe design for which had failed were excluded (4 SNPs for TRAF6, including: rs76834869, rs116937713, rs117428647, rs5030416; 3 SNPs for MYD88 including: rs117598704, rs118081234, rs117074408). Finally, 1 SNP for TRAF6 (rs5030445) were success genetyped by SYBR Green 1 real-time PCR [17, 18], and 1 SNP for MYD88 (rs7744) was gene-typed by TaqMan real-time PCR.

One SNP primer sequence of $I L-1 R A P$ (rs766442), one SNP primer sequence of $I L-6$ (rs6946864) and 2 SNP primer sequences of $I L-6 R$ ( $r s 11265618$, rs4845626) were obtained from Pro. Peter Gergre-

Table 1. Data for cases with rheumatoid arthritis and controls

\begin{tabular}{|c|c|c|}
\hline Characteristic & $\begin{array}{c}\text { Cases, } \\
n\end{array}$ & $\begin{array}{c}\text { Controls, } \\
n\end{array}$ \\
\hline Mean age of disease onset (years) & 41.6 & 43.1 \\
\hline Proportion of females $(\%)$ & 76.51 & 74.94 \\
\hline Total subjects available & 162 & 188 \\
\hline
\end{tabular}

Table 2. Details of SNPs selected and genotyping sequence of primers/probes

\begin{tabular}{|c|c|c|c|}
\hline Name & $\begin{array}{l}\text { Chrosome } \\
\text { position }\end{array}$ & SNP & Primers/Probes \\
\hline MYD88 & $3 \mathrm{p} 22-\mathrm{p} 21.3$ & rs7744 & $\begin{array}{l}\text { CAATGTACCAGTATTTATACCTCTA[A/G]TGAAGCACAGAGA- } \\
\text { GAGGAAGAGAGC }\end{array}$ \\
\hline \multirow[t]{3}{*}{ TRAF6 } & $11 \mathrm{p} 12$ & rs5030445 & A GCGGGCGAGGAAGTGAGAAGGGACTGTAT \\
\hline & & & G GCGGGCAGGGCGGCGAGGAAGTGAGAAGGGACTGTAC \\
\hline & & & F AGTATTTTTAAAGAAAGTATTAACTGAAGGCTCTACC \\
\hline \multirow[t]{3}{*}{$I L-1 R A P$} & $3 q 28$ & rs766442 & G GCGGGCAGGGCGGCGGCATCAAGCTCTACATATATTAG \\
\hline & & & T GCGGGCGGCATCAAGCTCTACATATATTAT \\
\hline & & & R GGTGTAACATGAATACATAAAACTGC \\
\hline \multirow[t]{3}{*}{$I L-6$} & $7 \mathrm{p} 21$ & rs6946864 & $\begin{array}{l}\text { G GCGGGCAGGGCGGCGGGAGACACATGTAAGTCATCATT } \\
\text { CTCGG }\end{array}$ \\
\hline & & & T GCGGGCGGGAGACACATGTAAGTCATCATTCTCGT \\
\hline & & & R GAGATGCTACTACTCTCTCTATGTCTACTAGAATTG \\
\hline \multirow[t]{6}{*}{$I L-6 R$} & $1 \mathrm{q} 21.3$ & rs11265618 & C GCGGGCAGGGCGGCGCACTATTGGCTGACTTTTCTGAAG \\
\hline & & & T GCGGGCGCACTATTGGCTGACTTTTCTGAAA \\
\hline & & & F GGTCATTGGTTTTGTCATTCATTTCC \\
\hline & & rs4845626 & F GGATTAGAGCCATCCCTGTTCTCA \\
\hline & & & G GCGGGCAGGGCGGCTTGTCAGAGCCTGGACTGTATCC \\
\hline & & & T GCGGGCTTGTCAGAGCCTGGACTGTATCA \\
\hline
\end{tabular}


son. The SNP sites of all these genes are shown in Table 2.

DNA extraction. A RelaxGene blood DNA system was used for DNA extraction. From all participants, blood samples were taken, and genomic DNA was isolated by using DNA isolation kit purchased from TIANGEN BIOTECH (Beijin, China) according to the manufacturer's guidelines.

Genotyping. Six SNPs (rs5030445, rs7744, rs766442, rs6946864, rs11265618, rs4845626) were genotyped by the method of SYBR Green I real-time PCR. One SNP (rs7744) was genotyped by the method of TaqMan real-time PCR. All SNP analysis were performed using a LightCycler® 480 Instrument system (Roche Diagnostics, Mannheim, Germany) $[17,18]$. The total volume of the TaqMan real-time PCR was $10 \mu$ l containing $25 \mathrm{ng}$ of genomic DNA, TaqMan Universal PCR Master Mix $5 \mu \mathrm{l}, 0.25 \mu \mathrm{l}$

Table 3. Distribution of genotype frequency

\begin{tabular}{|c|c|c|c|c|}
\hline Gene & $\begin{array}{c}\mathrm{Pa}- \\
\text { tients } \\
(n= \\
=162)\end{array}$ & $\begin{array}{l}\text { Cont- } \\
\text { rols }(n= \\
=188)\end{array}$ & $\chi^{2}$ & $\begin{array}{c}\mathrm{p} \\
\text { value }\end{array}$ \\
\hline \multicolumn{5}{|c|}{ MYD88 rs7744 } \\
\hline $\mathrm{AA}$ & 60 & 74 & 0.202 & 0.904 \\
\hline $\mathrm{AG}$ & 82 & 92 & & \\
\hline GG & 20 & 22 & & \\
\hline \multicolumn{5}{|c|}{ TRAF6 rs5030445 } \\
\hline $\mathrm{AA}$ & 1 & 3 & 1.742 & 0.419 \\
\hline $\mathrm{AG}$ & 36 & 50 & & \\
\hline GG & 125 & 135 & & \\
\hline \multicolumn{5}{|c|}{$I L-1 R A P$ rs766442 } \\
\hline GG & 0 & 3 & 6.564 & 0.038 \\
\hline GT & 30 & 51 & & \\
\hline TT & 132 & 134 & & \\
\hline \multicolumn{5}{|c|}{$I L-6$ rs6946864 } \\
\hline GG & 34 & 53 & 2.418 & 0.299 \\
\hline GT & 93 & 98 & & \\
\hline TT & 35 & 37 & & \\
\hline \multicolumn{5}{|c|}{$I L-6 R$ rs 11265618} \\
\hline $\mathrm{CC}$ & 129 & 167 & 5.684 & 0.058 \\
\hline CT & 31 & 20 & & \\
\hline $\mathrm{TT}$ & 2 & 1 & & \\
\hline \multicolumn{5}{|c|}{$I L-6 R$ rs 4845626} \\
\hline GG & 131 & 166 & 3.802 & 0.149 \\
\hline GT & 30 & 21 & & \\
\hline TT & 1 & 1 & & \\
\hline
\end{tabular}

of TaqMan probe (Applied Biosystems Inc.). The PCR comprised a pre-incubation step $\left(95^{\circ} \mathrm{C}\right.$ for $10 \mathrm{~min}), 40$ cycles $\left(95^{\circ} \mathrm{C}\right.$ for $15 \mathrm{sec}, 60^{\circ} \mathrm{C}$ for $1 \mathrm{~min})$ and a cooling step $\left(40^{\circ} \mathrm{C}\right.$ for $\left.30 \mathrm{sec}\right)$.

The total volume of the SYBR Green I realtime PCR was $20 \mu \mathrm{l}$ containing $25 \mathrm{ng}$ of genomic DNA, $10 \times$ PCR buffer, $2.5 \mathrm{mM}$ of dNTP Mix, $0.4 \mu \mathrm{M}$ of forward and reverse primer, $0.8 \mu \mathrm{M}$ of another primer, SYBR Green I and $5 \mathrm{U} / \mu \mathrm{l}$ Taq HS (above-mentioned obtained from TaKaRa Biotechnology (Dalian), China). The PCR comprised an initial denaturation step $\left(95^{\circ} \mathrm{C}\right.$ for $\left.5 \mathrm{~min}\right), 31$ cycles (denaturation at $95^{\circ} \mathrm{C}$ for $10 \mathrm{sec}$, primer annealing at $60{ }^{\circ} \mathrm{C}$ for $15 \mathrm{sec}$, extension at $72{ }^{\circ} \mathrm{C}$ for $15 \mathrm{sec})$. The melting curve analysis comprised a heating step $\left(95^{\circ} \mathrm{C}\right.$ for $\left.5 \mathrm{sec}\right)$, a step rapidly lowering the temperature to $65{ }^{\circ} \mathrm{C}$ and holding for $1 \mathrm{~min}$. The final step was cooling the temperature down to $40{ }^{\circ} \mathrm{C}$ for $30 \mathrm{sec}$.

Statistical analysis. Each genetic marker was tested for Hardy-Weinberg equilibrium in the control population $[19,20]$. Single-marker allelic tests were performed with Fisher's exact test. All tests were two-tailed, considering $\mathrm{P}$ values $<0.05$ as significant. Both allelic and genotypic associations between single SNPs and RA susceptibility were analyzed using $\chi^{2}$ tests [21].

Results. Hardy-Weinberg equilibrium test was satisfied in the observed genotype frequencies for all groups. The genotype and allele distribution for studied polymorphic variants is shown in Table 3 and 4 for the following results.

Genotype frequency and allele-frequency of MYD88 rs 7744. The results indicated that there were no statistically significant differences in genotype and allele distribution between case and control group $(\mathrm{P}=0.904, \mathrm{P}=0.685)$.

Genotype frequency and allele-frequency of TRAF6 $r s 5030445$. The statistically significant differences were not found in genotype and allele distribution between case and control group $(\mathrm{P}=0.419, \mathrm{P}=0.221)$.

Genotype frequency and allele-frequency of $I L-$ $1 R A P$ rs 766442. From the results, we found that GG-homozygote was the rarest type and not founded in RA case groups. Through Fisher's test, there were statistically significant differences in genotype and allele distribution between case and control group $(\mathrm{P}=0.038, \mathrm{P}=0.018)$.

Genotype frequency and allele-frequency of IL-6 rs6946864. GT-heterozygote was the most common 
form for these two receptors groups, but the difference among GG-genotypes, TT-genotypes, and GT-genotypes had no statistical significance, so did $\mathrm{G} / \mathrm{T}$ allele-frequency $(\mathrm{P}=0.299, \mathrm{P}=0.228)$.

Genotype frequency and allele-frequency of $I L-6 R$ rs 11265628 and $r s 4845626$. For rs11265628, there were no statistically significant differences in genotype and allele distribution between case and control group $(\mathrm{P}=0.058)$, and the difference in $\mathrm{C} / \mathrm{T}$ allele-frequency had statistical significance $(\mathrm{P}=$ $=0.017$ ).

For rs4845626, there were no statistically significant differences in genotype and allele distribution between case and control group $(\mathrm{P}=0.149, \mathrm{P}=$ $=0.065$ ).

Discussion. Signal transmission of TLRs. TLR is defined as a process that the membrane transport receptors identify different ligands through the comprehensive repeating structure of leucine in structural domain outsides its cells [22, 23]. TLR signal medium active the signal pathway of inflammation and withering. TLR/IL-1R signal pathway can be realized through two ways: MYD88dependence and Myd88-independence [24]. The former one can be described as follows: 1) the combination of TIR structural domain between Cterminal of Myd88 and TLR, L-1R, and IL-18R; 2) collect IL-1R associated kinase (IRAK) in the $\mathrm{N}$-terminal death domain; 3) the combination of tumor necrosis factor receptor-associated factor 6 (TARF6), $\beta$-type TAK1 and TAB1 and TAB2, get into downstream of signal transmission; 4) I-KB kinase (IKK1-IKK2-IKK) active-KB (NF-kB), or Mitogen-activated protein kinase (MARK) induce conveying of inflammation cells, such as IL-1, IL6, IL-12, TNF- $\alpha$, interferon (IFN) and adhesion molecules. Both ways are through activator protein (AP-1) [25-28]. TRAF6 is a kind of terminal kinase signal to modify NF-kB and Jun, so the loss of TARF6 may lead to defection of TLR signal, restraining the activation of NF-kB and reducing the inflammation cells nosogenesis [29-31].

Two IL-6 signal transmission ways: Both of traditional receptors' combination and dissolvable receptors' combination need the participation of IL$6 \mathrm{R}$ and membrane transport protein gp130 [32, 33]. Traditional signal transmission is the combination of IL-6 and IL-6R in the surface, and this complex cross-link with gp130 into homo-signal. The same result can be realized by sIL-6R, a dissolvable form of IL-6R, and this is the dissolvable way. These two transmission ways can be achieved by the cascading of Janus kinase/signal transducer and activator of transcription and mitogen-activated protein kinase (MARK). IL-6/IL-6R/gp130 complex crosslink with JAK in cytoplasm, and promotes the conveying of Acute Phase Reactants (APA), and finally leads to the over-breed of inflammation cells and the damage of natural autoantibody [34-36].

The relevance between $S N P$ and $R A$ susceptible gene. TLR downstream molecules, such as MYD88, TARF6, IL-1RAP, IL-6, IL-6R, were related to the attack of RA. We have chosen 6 SNP sites (rs7744, rs5030445, rs766442, rs6946864, rs11265618, and rs4845626), and found that $I L-1 R A P$ rs766442 and $I L-6 R$ rs 1126518 allele-frequency makes sense statistically. So this proves that there is obvious relevance between nucleic acid polymorphism of $I L$ $1 R A P, I L-6 R$ and RA susceptible genes. And it also proved that G-type alleles of $I L-1 R A P$ rs 766442 may be protecting genes of RA, while T-type alleles of $I L-6 R$ rs 11265618 and $I L-1 R A P$ rs766442 may be susceptible genes of RA. Moreover, statistical analysis also showed that there was no relevance

Table 4. Distribution of allele-frequency

\begin{tabular}{l|r|r|c|c}
\hline \multicolumn{1}{c|}{ Gene } & $\begin{array}{c}\text { Pa- } \\
\text { tients } \\
(n= \\
=162)\end{array}$ & $\begin{array}{c}\text { Cont- } \\
\text { rols }(n= \\
=188)\end{array}$ & $\chi^{2}$ & $\begin{array}{c}\mathrm{p} \\
\text { value }\end{array}$ \\
\hline $\begin{array}{l}\text { MYD88 rs7744 } \\
\mathrm{A}\end{array}$ & 202 & 240 & 0.165 & 0.685 \\
$\mathrm{G}$ & 122 & 136 & & \\
TRAF6 rs5030445 & & & & \\
$\mathrm{A}$ & 38 & 56 & 1.500 & 0.221 \\
$\mathrm{G}$ & 286 & 320 & & \\
$I L-1 R A P$ rs766442 & & & & \\
$\mathrm{G}$ & 30 & 57 & 5.567 & 0.018 \\
$\mathrm{~T}$ & 294 & 319 & & \\
$I L-6$ rs6946864 & & & & \\
$\mathrm{G}$ & 161 & 204 & 1.453 & 0.228 \\
$\mathrm{~T}$ & 163 & 172 & & \\
$I L-6 R$ rs11265618 & & & & \\
$\mathrm{C}$ & 289 & 354 & 5.704 & 0.017 \\
$\mathrm{~T}$ & 35 & 22 & & \\
$I L-6 R$ rs4845626 & & & & \\
$\mathrm{G}$ & 292 & 353 & 3.398 & 0.065 \\
$\mathrm{~T}$ & 32 & 23 & & \\
\hline
\end{tabular}


between MYD88 rs7744, TRAF6, IL-6 rs6946864 with RA. But owing to limited number of samples, the result could not be exclusive of the possibility of False Negative Rate (FNR), and the sites with statistical meaning can be caused by False Positive Rate (FPR). So, there is a necessity to expand the number of samples, in that case, we can know the relevance between SNP in the downstream of TLRs signal transduction pathway and RA Susceptible genes.

In conclusion, the studies on the nucleis acid polymorphism in TLRs signal pathway contribute to disclose genes' influence on the attack mechanism of RA, early diagnosis and treatment of RA.

The study was supported by Shandong Province young scientist in incentive fund (Grant № 2006BS03018) and National Natural Science Foundation of China (Grant № 30801025).

X. Liu, J. Xu, C.D. Hu, Z.L. Pan, Y.C. Zhang

АССОЦИАЦИЯ SNP В ГЕНАХ

ЭЛЕМЕНТОВ СИГНАЛЬНЫХ ПУТЕЙ ТLR

С ПРЕДРАСПОЛОЖЕННОСТЬЮ

К РЕВМАТОИДНОМУ АРТРИТУ

Толл-подобные рецепторы (TLRs) играют важную роль в индукции и регуляции врожденной иммунной системы или адаптивных иммунных ответах Показано, что что генетическая изменчивость TLRs человека связана с ревматоидным артритом (РА). Целью настоящей работы было изучение корреляций между однонуклеотидным полиморфизмом в сигнальной трансдукции TLRs и генами предрасположенности к PA. G-тип IL-1RAP rs766442 могут быть генами, предохраняющими от РА, в то время как аллели Т-типа IL-6R rs11265618 и IL-1RAP rs766442 могут быть генами чувствительности к РА. Изучение полиморфизма нуклеиновых кислот в сигнальном пути TLRs может внести вклад в выявление участия генов в механизмах приступов РА, раннюю диагностику и лечение РА.

\section{REFERENCES}

1. Szekanecz,Z., Koch A.E. Macrophages and their products in rheumatoid arthritis // Curr. Opin. Rheumatol. - 2007. - 19. - P. 289-295.

2. Hoffinann J.A., Kaaftos F.C., Janeway C.A., Ezekowitz R.A.B. Phylogenetic perspectives in innateimmunity // Science. - 1999. - 284. - P. 1313-1318.

3. Friestein G.S. Evolving concepts of rheumatoid arthritis // Nature. - 2003. - 423. - P. 356-361.

4. Alieva V.S., Karimov K.Y., Nazarov A.A. et al. Analysis of CTLA4 gene 49A/G polymorphism association with development of allergic rhinitis // Cytology and Genetics. - 2010. - 44. - P. 140-143.

5. Barton A., Jury F., Eyre S. et al. Haplotype analysis in simplex families and novel analytic approaches in a case-control cohort reveal no evidence of association of the CTLA-4 gene with rheumatoid arthritis // Arthrit. Rheum. - 2004. - 50. - P. 748-752.

6. Izmailova O.V., Shlykova O.A., Bobrova N.O., Kaidashev I.P. Relationship between the TLR2 and TLR4 gene polymorphisms with a predisposition to certain urogenital infections // Cytology and Genetics. 2011. - 45. - P. 225-230.

7. Cohen S., Dadi H., Shaoul E. et al. Cloning and characterization of a Lymphoid-specific, inducible human protein tyrosine phosphatase // Lyp Blood. - 1999. 93. - P. 2013-2024.

8. Shakhbazau A.V., Kosmacheva S.M., Kartel N.A., Potapnev M.P. Gene therapy based on human mesenchymal stem cells: strategies and methods // Cytology and Genetics. - 2010. - 44. - P. 61-65.

9. Sheremet Y.A., Yemets A.I., Azmi A. et al. Effects of tyrosine kinase and phosphatase inhibitors on mitosis progression in synchronized tobacco BY-2 cells // Cytology and Genetics. - 2012. - 46. - P. 263-271.

10. Joosten L.A., Koenders M.I., Smeets R.L. Toll-like receptor 2 pathway drives strep to coccal cell wallinduced joint in flammation: critical role of myeloid differentiation factor 88 // J. Immunol. - 2003. 171. - P. 6145-6153.

11. Tanaka T., Kishimoto T. Targeting interleukin-6: all the way to treat autoimmune and inflammatory diseases // Int. J. Biol. Sci. - 2012. - 8. - P. 1227-1236.

12. Dayer J.M., Choy E. Therapeutic targets in rheumatoid arthritis: the interleukin-6 receptor // Rheumatology (Oxford). - 2010. - 49. - P. 15-24.

13. Dinarello C.A. Immunological and inflammatory functions of the interleukin-1 family // Annu. Rev. Immunol. - 2009. - 27. - P. 519-550.

14. Sacre S.M., Andreakos E., Kiriakidis S. et al. The tolllike receptor adaptor protein MYD88 contributes to the inflammatory and destructive processes in a human model of rheumatoid arthritis // Amer. J. Pathol. - 2007. - 170, № 2. - P. 518-525.

15. Zhu L.J., Zheng D.H., Mo Y.Q. et al. Upregulation of tumor necrosis factor receptor-associated factor 6 correlated with synovitis severity in rheumatoid arthritis // Arthrit. Res Ther. - 2012. - 14, № 3. - R133.

16. Arnett F.C., Edworthy S.M., Bloch D.A. The American Rheumatism Association 1987 revised criteria for the classification of rheumatoid arthritis // Arthrit. Rheum. - 1988. - 31. - P. 315-324.

17. Audrey C.P., Julia K.P., Glen C. Single nucleotide polymorphism genotyping using allele-specific PCR and fluorescence melting curves // BioTechniques. 2003. - 34. - P. 1068-1072. 


\section{The relationship between snps in the genes of TLR signal transduction pathway}

18. Wang J., Chuang K., Ahluwalia W. et al. Highthroughput SNP genotyping by single-tube PCR with Tm-shift primers // BioTechniques. - 2005. - 39. P. 885-893.

19. Gabriel S.B., Schaffner S.F., Nguyen H. et al. The structure of haplotype blocks in the human genome // Science. - 2002. - 296. - P. 2225-2229.

20. Barrett J.C., Fry B., Maller J., Daly M.J. Haploview: analysis and visualization of LD and haplotype maps // Bioinformatics. - 2005. - 21. - P. 263-265.

21. Kutsokon N.K. Main trends in the genetic transformation of Populus species // Cytology and Genetics. - 2011. - 45. - P. 352-361.

22. Lamb R., Zeggini E., Thomson $W$. Toll-like receptor 4 gene polymorphisms and susceptibility to juvenile idiopathic arthritis // Ann. Rheum Dis. - 2005. 64. - P. 767-769.

23. Kutsenko N.L., Izmailova O.V., Vesnina L.E., Kaidashev I.P. Role of toll-like receptor 2 and 4 gene polymorphisms in the development of allergic disease with increased IgE levels // Cytology and Genetics. 2012. - 46. - P. 379-383.

24. Janssens S., Beyaert R.A. Universal role for MyD88 in TLR/IL-1R-mediated signaling // Trends Biochem Sci. - 2009. - 27. - P. 474-482.

25. Ye H., Arron J.R., Lamothe B. et al. Distinct molecular mechanism for initiating TRAF6 signalling // Nature. - 2002. - 418. - P. 443-447.

26. Kyrychenko A.M., Kovalenko O.G. Genetic basis and functioning of the signal transduction system in plants under the conditions of viral resistance // Cytology and Genetics. - 2011. - 45. - P. 249-258.

27. Greenhill C.J., Rose-John S., Lissilaa R. et al. IL-6 trans-signaling modulates TLR4-dependent inflammatory responses via STAT3 // J. Immunol. - 2011. 186. - P. 1199-1208.

28. Shablii V.A., Lukash L.L., Lobintseva G.S. The role of some donor-host cell interactions under a microenvironmental influence during regeneration precesses // Cytology and Genetics. - 2012. - 46. - P. 180-187.
29. Catherine P., Stephen E., Andrew C., Worthington J., Barton $A$. Investigation of association between the TRAF family genes and RA susceptibility // Ann. Rheum. Dis. - 2007. - 66. - P. 1322-1326.

30. Huang $Q$., $M a Y$. Increased macrophage activation mediated through Toll-like receptors in rheumatoid arthritis // Arthrit. Rheum. - 2007. - 56. - P. 21922201.

31. Kravchenko N.A., Yarmysh N.V. Regulation of the expression of endothelial nitric oxide synthase and dysfunction of vascular endothelium in cardiovascular pathology // Cytology and Genetics. - 2008. - 42. P. 278-288.

32. Kamimura D., Ishihara K., Hirano T. IL-6 signal transduction and its physiological roles : the signal or chestration model // Rev. Physiol. Biochem. Pharmacol. - 2003. - 149. - P. 1-38.

33. Murakami M., Nishimoto $N$. The value of blocking IL-6 outside of rheumatoid arthritis: current perspective // Curr. Opin. Rheumatol. - 2011. - 23. P. 273-277.

34. Kravchenko N.A., Yarmysh N.V. Role of PPAFs and their isoforms in metabolic disorders related to insulin resistance and diabetes // Cytology and Genetics. 2011. - 45. - P. 191-199.

35. Lypez-Mejías R., García-Bermúdez, M., González-Juanatey $C$. et al. Lack of association of IL6R rs2228145 and IL6ST/gp130 rs2228044 gene polymorphisms with cardiovascular disease in patients with rheumatoid arthritis // Tissue Antigens. - 2011. - 78, № 6. - P. 438-441.

36. Areshkov P.A., Kavsan V.M. Chitinase 3-like protein 2 (CHI3L2, YKL-39) activates phosphorylation of extracellular signal-regulated kinases ERK1/ERK2 in human embryonic kidney (HEK293) and human glioblastoma (U87MG) cells // Cytology and Genetics. -2010 . - 44. - P. 1-6.

Received 22.12.12 